\title{
OCCUPATIONAL EXPOSURE TO PARTICULATE MATTER IN 2 PORTUGUESE WASTE-SORTING UNITS
}

\author{
SUSANA VIEGAS ${ }^{1,2}$, MARINA ALMEIDA-SILVA $^{1,3}$, and CARLA VIEGAS ${ }^{1}$ \\ ${ }^{1}$ Polytechnic Institute of Lisbon, Portugal \\ Environmental Health RG - Lisbon School of Health Technology \\ ${ }^{2}$ New University of Lisbon, Portugal \\ Center for Malaria \& Tropical Diseases (CMDT) - Public Health and Policy, Escola Nacional de Saúde Pública \\ ${ }^{3}$ University of Lisbon, Loures, Portugal \\ C2TN, Instituto Superior Técnico
}

\begin{abstract}
Objectives: This study intended to characterize work environment contamination by particles in 2 waste-sorting plants. Material and Methods: Particles were measured by portable direct-reading equipment. Besides mass concentration in different sizes, data related with the number of particles concentration were also obtained. Results: Both sorting units showed the same distribution concerning the 2 exposure metrics: particulate matter $5\left(\mathrm{PM}_{5}\right)$ and particulate matter $10\left(\mathrm{PM}_{10}\right)$ reached the highest levels and $0.3 \mu \mathrm{m}$ was the fraction with a higher number of particles. Unit B showed higher $(\mathrm{p}<0.05)$ levels for both exposure metrics. For instance, in unit B the $\mathrm{PM}_{10}$ size is 9-fold higher than in unit $\mathrm{A}$. In unit A, particulate matter values obtained in pre-sorting and in the sequential sorting cabinet were higher without ventilation working. Conclusions: Workers from both waste-sorting plants are exposed to particles. Particle counting provided additional information that is of extreme value for analyzing the health effects of particles since higher values of particles concentration were obtained in the smallest fraction.
\end{abstract}

Key words:

Occupational exposure, Waste-sorting, Particulate matter, Particles, Size distribution

\section{INTRODUCTION}

In order to reduce current environmental problems, the industrialized world has made plans aiming to increase the recycling of domestic waste. This goal has being accomplished in Portugal with the opening of several wastesorting units since 1995.

Domestic waste includes different types of materials, namely non-biodegradable waste such as plastic materials, metals, glass, paper and cardboard; and non-separated general waste. Most of the non-biodegradable waste represents an important recyclable fraction composed normally of paper, cardboard, plastic materials, wood, glass, and metals. These kinds of waste are sorted at refuse transfer stations to produce raw materials for recycling, and this process usually requires direct waste contact on the part of workers [1].

Although a high amount of research has been focused on the health of the population living near waste disposal

The study was financially supported by the Lisbon School of Health Technology. The research project: "Occupational exposure to particles and fungi in the waste management setting." Coordinators: Carla Viegas and Susana Viegas.

Received: December 30, 2013. Accepted: June 5, 2014.

Corresponding author: S. Viegas, Environmental Health RG - Lisbon School of Health Technology - Polytechnic Institute of Lisbon, av. D. João II, lote 4.69.01, Parque das Nações, 1990-096 Lisboa, Portugal (e-mail: susana.viegas@estesl.ipl.pt). 
sites, reports on occupational health problems related to air contamination are still scarce and not always describe the situation with the detail needed. Additionally, it is important to consider that workers may be exposed to the same potential hazards as the general population, although the exposure and the risk may be different due to the waste handling by workers and, consequently, the proximity to emission sources and staying in a more contaminated indoor environment [2].

Management of solid waste involves normally the release of a wide range of chemical and biological pollutants with potential adverse health effects. Research studies have demonstrated that sorting and recycling industry is associated with occupational health problems such as irritation, allergy, inflammation, and toxicity, mainly affecting eyes, throat, skin, and lungs and also being the cause of gastrointestinal and musculoskeletal disorders [1,3-9]. Some of these symptoms were already related with exposure to high levels of particles and bioaerosols [3,10-13]. Knowing the exposure to all of these different agents in detail will allow the adoption of measures aiming to prevent the exposure and to protect workers' health.

This study intended to describe some of the features of the occupational exposure to particulate matter in 2 wastesorting plants (WSPs) located in the outskirts of Lisbon, Portugal.

\section{MATERIAL AND METHODS}

\section{Waste-sorting plants (WSP) characterization}

Two WSPs located near the city of Lisbon, Portugal were considered and the days that were selected to perform the measurements and sampling were defined by the technicians in charge as being "normal," regarding the waste amount and operations involved.

Waste-sorting plant A has a maximum capacity of 90.5 ton/year of urban waste. This WSP works 5 days a week in a daily regimen of two 8-h shifts. None of the workers use respiratory protection devices. The sampling campaign was carried out in March 2013 and 7 workplaces were selected for measurement and sampling, namely: package reception (PR); waste without a sorting cabinet named pre-sorting (with mechanical ventilation) (CPS); waste with a sorting cabinet named sequential sorting (with mechanical ventilation) (CSS); ferrous waste cabinet (FWC); circulation zone (CZ); waste with a sorting cabinet (WSC); cabinet's waste storage zone (CWSZ); waste without a sorting cabinet (WWSC); forklift cabinet driver zone (FCD); and an outdoor reference sample.

Waste-sorting plant $B$ has a maximum capacity of 150000 ton/year of urban waste. This WSP operates 5 days a week with a daily regimen of two 8-h shifts. In contrast to what was noted in WSP A, workers had at their disposal respiratory protection devices.

The sampling campaign was performed in March 2011 and the 5 workplaces considered were: waste entrance hall (1 point); near the paper belt conveyer (2 points) (SPBC1 and SPBC2); near the low-density polyethylene belt conveyer (2 points) (SLDPE1 and SLDPE2); and an outdoor reference sample. There were no mechanical ventilation resources available in this plant.

\section{Particulate matter assessment}

Measurements of particulate matter (PM) were performed using a portable direct-reading equipment (Lighthouse, model 3016 IAQ) that gives in-

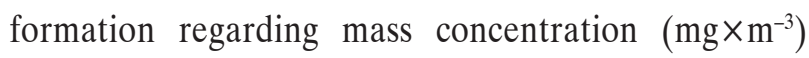
in 5 different sizes $\left(\mathrm{PM}_{0.5}, \mathrm{PM}_{1}, \mathrm{PM}_{2.5}, \mathrm{PM}_{5}, \mathrm{PM}_{10}\right)$. Additionally, data related with particle number concentration by each diameter size were also obtained with the same equipment. In this case, particles results were given in 6 different diameter sizes, namely: $0.3 \mu \mathrm{m}, 0.5 \mu \mathrm{m}, 1 \mu \mathrm{m}, 2.5 \mu \mathrm{m}, 5 \mu \mathrm{m}$ and $10 \mu \mathrm{m}$. As mentioned in some literature, these data were also collected because they might be more closely correlated with adverse PM health effects $[14,15]$. 
The measurements were conducted near each worker's nose and during tasks performance. One measurement with the duration of $5 \mathrm{~min}$ was done in each workplace, and the results were obtained by calculating the average for each sampling period. The measurements were performed during the most common task, with the typical conditions regarding ventilation, amount of waste inside the units, number of workers and machines. In CPS and in CSS from WSP A, 2 measurements were made: one with ventilation turned on and another with ventilation turned off.

\section{Statistical analysis}

The statistical analysis of all data was performed using the Statistica software, version 10. The Mann-Whitney U-test was applied to detect statistically significant differences between the 2 waste-sorting units, since the distributions were non-parametric. The criterion for significance was set at $\mathrm{p}<0.05$.

\section{RESULTS}

Considering mass concentration, particles with bigger sizes were responsible for higher levels of contamination, particularly $\mathrm{PM}_{5}$ and $\mathrm{PM}_{10}$. The distribution of sizes showed the same tendency in both WSPs (Table 1).

Waste-sorting plant B presented significantly $(\mathrm{p}<0.05)$ higher levels of contamination for all particles sizes. For instance, the $\mathrm{PM}_{10}$ size was 9-fold higher than in WSP A. In WSP B, the highest PM values were found for 1 of the measurements done near the sorting belt conveyer (SPBC) (Figure 1). In WSP A, the workplace with the highest PM mass concentration was FCD.

In pre-sorting and in a sequential sorting cabinet from WSP A, all the values were higher without ventilation working (Figure 2). However, the statistical analysis showed that the level of particles measured without the ventilation system working was not significantly higher
Table 1. Particulate matter (PM) results in both waste-sorting plants (WSP)

\begin{tabular}{|c|c|c|}
\hline \multirow{2}{*}{ Parameter } & \multicolumn{2}{|c|}{$\begin{array}{l}\text { Particulate matter concentration } \\
\qquad\left(\mathrm{mg} \times \mathrm{m}^{-3}\right)\end{array}$} \\
\hline & WSP A & WSP B \\
\hline \multicolumn{3}{|l|}{$\mathrm{PM}_{0.5}$} \\
\hline M & $4.41 \times 10^{-3}$ & $1.70 \times 10^{-2}$ \\
\hline $\mathrm{SD}$ & $1.90 \times 10^{-3}$ & $3.51 \times 10^{-3}$ \\
\hline $\min$. & $2.77 \times 10^{-3}$ & $1.10 \times 10^{-2}$ \\
\hline $\max$ & $8.07 \times 10^{-3}$ & $1.95 \times 10^{-2}$ \\
\hline $\mathrm{Me}$ & $3.42 \times 10^{-3}$ & $1.87 \times 10^{-2}$ \\
\hline \multicolumn{3}{|l|}{$\mathrm{PM}_{1}$} \\
\hline $\mathrm{M}$ & $8.36 \times 10^{-3}$ & $3.23 \times 10^{-2}$ \\
\hline SD & $2.75 \times 10^{-3}$ & $7.63 \times 10^{-3}$ \\
\hline $\min$. & $5.68 \times 10^{-3}$ & $2.02 \times 10^{-2}$ \\
\hline $\max$ & $1.40 \times 10^{-2}$ & $3.96 \times 10^{-2}$ \\
\hline $\mathrm{Me}$ & $7.17 \times 10^{-3}$ & $3.67 \times 10^{-2}$ \\
\hline \multicolumn{3}{|l|}{$\mathrm{PM}_{2.5}$} \\
\hline M & $2.75 \times 10^{-2}$ & $1.08 \times 10^{-1}$ \\
\hline $\mathrm{SD}$ & $7.22 \times 10^{-3}$ & $2.68 \times 10^{-2}$ \\
\hline $\min$. & $1.59 \times 10^{-2}$ & $7.89 \times 10^{-2}$ \\
\hline $\max$ & $3.86 \times 10^{-2}$ & $1.44 \times 10^{-1}$ \\
\hline $\mathrm{Me}$ & $2.69 \times 10^{-2}$ & $1.05 \times 10^{-1}$ \\
\hline \multicolumn{3}{|l|}{$\mathrm{PM}_{5}$} \\
\hline M & $9.67 \times 10^{-2}$ & $6.29 \times 10^{-1}$ \\
\hline SD & $4.53 \times 10^{-2}$ & $2.13 \times 10^{-1}$ \\
\hline $\min$. & $5.03 \times 10^{-2}$ & $9.15 \times 10^{-1}$ \\
\hline $\max$ & $2.00 \times 10^{-1}$ & $4.04 \times 10^{-1}$ \\
\hline $\mathrm{Me}$ & $8.02 \times 10^{-2}$ & $5.48 \times 10^{-1}$ \\
\hline \multicolumn{3}{|l|}{$\mathrm{PM}_{10}$} \\
\hline M & $1.49 \times 10^{-1}$ & $1.39 \times 10^{0}$ \\
\hline $\mathrm{SD}$ & $8.92 \times 10^{-2}$ & $4.73 \times 10^{-1}$ \\
\hline $\min$. & $7.86 \times 10^{-2}$ & $8.33 \times 10^{-1}$ \\
\hline $\max$ & $3.60 \times 10^{-1}$ & $1.98 \times 10^{0}$ \\
\hline $\mathrm{Me}$ & $1.10 \times 10^{-1}$ & $1.42 \times 10^{0}$ \\
\hline
\end{tabular}

M - mean; SD - standard deviation; min. - minimum value; max maximum value; $\mathrm{Me}$ - median. 


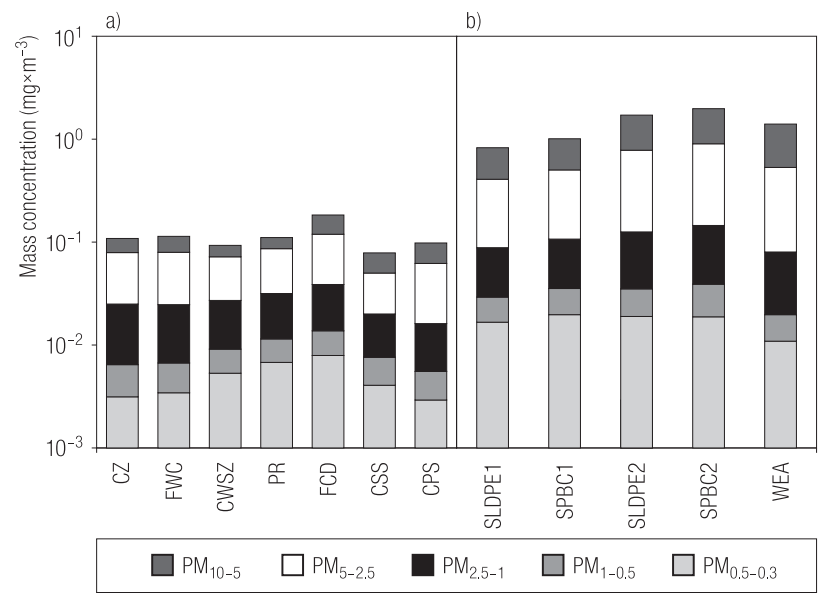

CZ - circulation zone; FWC - ferrous waste cabinet; CWSZ - cabinet's waste storage zone; PR - package reception; FCD - forklift cabinet driver; CSS - cabinet: sequential sorting with ventilation; CPS - cabinet: pre-sorting with ventilation; SLDPE1 and SLDPE2 sorting low-density polyethylene; SPBC1 and SPBC2 - sorting belt conveyer; WEH - waste entrance hall; WSP - waste-sorting plants.

Fig. 1. Particulate matter (PM) distribution by workplace: a) WSP A and b) WSP B

( $p=0.53$ and $p=0.83$ for pre-sorting and sequential sorting, respectively).

Considering the particle number concentration, in both WSPs, the particle fraction with the highest number in all workplaces (measurements points) was $0.3 \mu \mathrm{m}$ (WSP

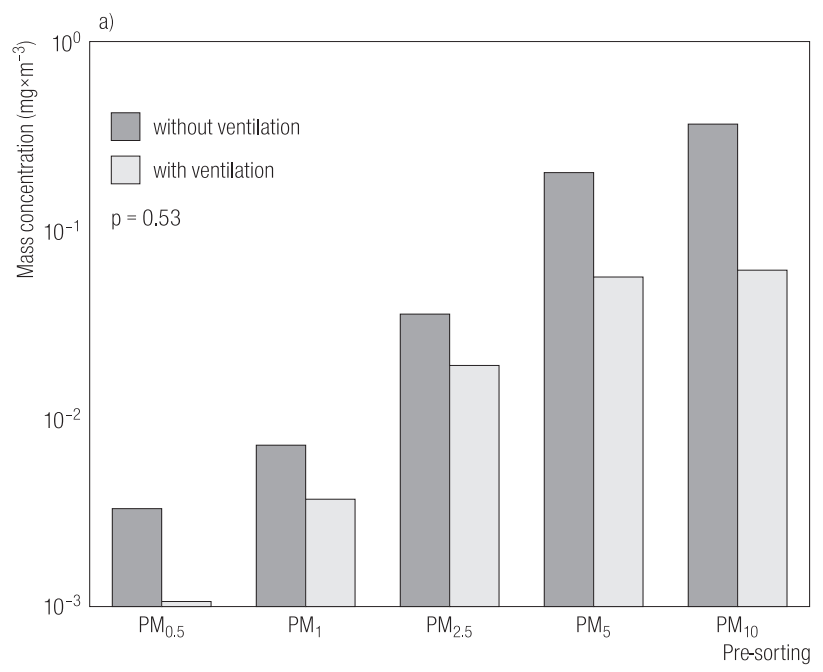

A: 745 097.9 \pm 320 519.8; WSP B: 2872 981.2 \pm 593 450.2). Waste-sorting plant B presented a significantly $(\mathrm{p}<0.05)$ higher particle number concentration for all fractions than WSP A (Table 2).

\section{DISCUSSION}

Our findings allow us to obtain a screening of the workplaces with a probably higher exposure and also to demonstrate the influence of ventilation on PM contamination and, consequently, on the exposure.

The method used to measure PM allowed to achieve relevant information regarding their size distribution; this aspect is determinant to estimate the possible resultant health effects. It was possible to measure 5 different sizes that can be distinguished in the inhalable fraction $\left(\mathrm{PM}_{5}\right.$ and $\left.\mathrm{PM}_{10}\right)$ and in the respirable fraction $\left(\mathrm{PM}_{0.5}, \mathrm{PM}_{1}, \mathrm{PM}_{2.5}\right)[16,17]$. Moreover, studies developed in waste management settings consider normally only the inhalable dust or the total dust and do not distinguish or provide data related with the respirable fraction $[1,5,18]$.

The obtained results indicate that workers from both WSPs are exposed to PM, particularly to $\mathrm{PM}_{5}$ and $\mathrm{PM}_{10}$,

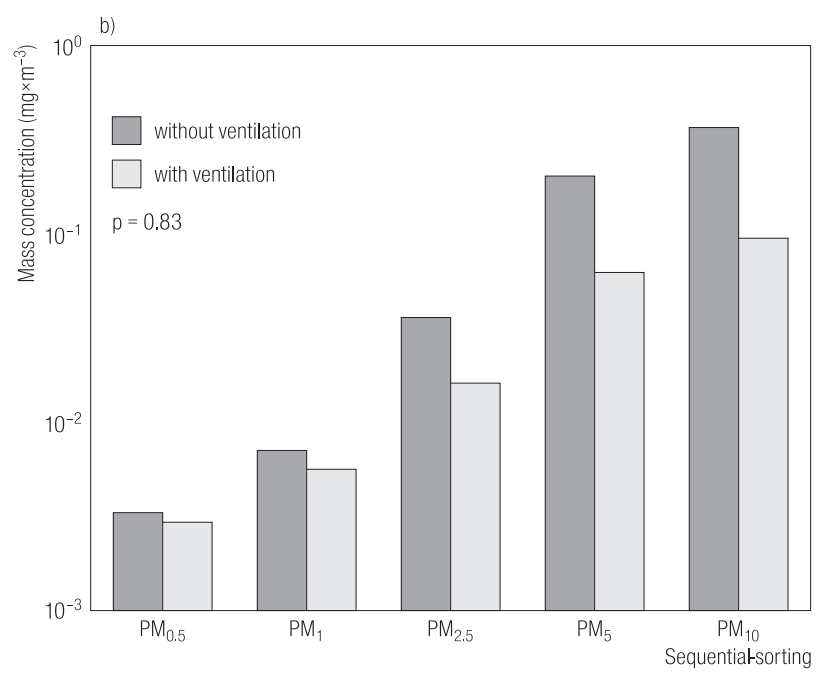

Fig. 2. Particulate matter (PM) results with and without ventilation in waste-sorting plant A: a) pre-sorting cabinet, b) sequential sorting cabinet 
Table 2. Particle number concentration in both waste-sorting plants (WSPs)

\begin{tabular}{|c|c|c|c|c|c|}
\hline \multirow{2}{*}{$\begin{array}{l}\text { Particle size } \\
\quad(\mu \mathrm{m})\end{array}$} & \multicolumn{5}{|c|}{$\begin{array}{l}\text { Particle number concentration } \\
\text { (counts) }\end{array}$} \\
\hline & $\mathrm{M}$ & SD & $\min$. & $\max$ & $\mathrm{Me}$ \\
\hline \multicolumn{6}{|l|}{ WSP A } \\
\hline 0.3 & $7.45 \times 10^{5}$ & $3.21 \times 10^{5}$ & $4.68 \times 10^{5}$ & $1.36 \times 10^{6}$ & $5.81 \times 10^{5}$ \\
\hline 0.5 & $1.01 \times 10^{5}$ & $2.33 \times 10^{4}$ & $7.08 \times 10^{4}$ & $1.51 \times 10^{5}$ & $9.68 \times 10^{4}$ \\
\hline 1.0 & $3.86 \times 10^{4}$ & $1.16 \times 10^{4}$ & $2.07 \times 10^{4}$ & $5.74 \times 10^{4}$ & $3.68 \times 10^{4}$ \\
\hline 2.5 & $1.42 \times 10^{4}$ & $8.24 \times 10^{3}$ & $6.24 \times 10^{3}$ & $3.36 \times 10^{4}$ & $1.10 \times 10^{4}$ \\
\hline 5.0 & $1.35 \times 10^{3}$ & $1.15 \times 10^{3}$ & $5.05 \times 10^{2}$ & $4.12 \times 10^{3}$ & $8.62 \times 10^{2}$ \\
\hline 10.0 & $7.79 \times 10^{2}$ & $6.60 \times 10^{2}$ & $2.40 \times 10^{2}$ & $2.18 \times 10^{3}$ & $4.40 \times 10^{2}$ \\
\hline \multicolumn{6}{|l|}{ WSP B } \\
\hline 0.3 & $2.87 \times 10^{6}$ & $5.93 \times 10^{5}$ & $1.86 \times 10^{6}$ & $3.30 \times 10^{6}$ & $3.19 \times 10^{6}$ \\
\hline 0.5 & $3.92 \times 10^{5}$ & $1.12 \times 10^{5}$ & $2.36 \times 10^{5}$ & $5.31 \times 10^{5}$ & $4.28 \times 10^{5}$ \\
\hline 1.0 & $1.53 \times 10^{5}$ & $4.12 \times 10^{4}$ & $1.17 \times 10^{5}$ & $2.11 \times 10^{5}$ & $1.39 \times 10^{5}$ \\
\hline 2.5 & $1.07 \times 10^{5}$ & $3.88 \times 10^{4}$ & $6.50 \times 10^{4}$ & $1.58 \times 10^{5}$ & $9.41 \times 10^{4}$ \\
\hline 5.0 & $1.95 \times 10^{4}$ & $2.73 \times 10^{4}$ & $1.10 \times 10^{4}$ & $7.04 \times 10^{3}$ & $2.26 \times 10^{4}$ \\
\hline 10.0 & $2.38 \times 10^{3}$ & $1.23 \times 10^{3}$ & $1.16 \times 10^{3}$ & $4.13 \times 10^{3}$ & $2.05 \times 10^{3}$ \\
\hline
\end{tabular}

Abbreviations as in Table 1.

and that there is a statistical difference between them and the other sizes $(p<0.05)$. These particles' sizes are related with negative health effects, namely the penetration into the gas exchange region of the lung $\left(\mathrm{PM}_{5}\right)$, and with the possibility to produce disease by impacting the upper and larger airways below the vocal cords $\left(\mathrm{PM}_{10}\right)[17,19]$. Recently, a study developed by Hebisch and Linsel (2012) [20] in recycling enterprises showed the same tendency in PM size distribution, with higher values of inhalable particles than of respiratory particles. The same tendency in size distribution, in what concerns mass concentration, was found in other research works developed in different occupational settings that implicate also exposure to organic dust, namely in swine and poultry production [21,22]. Although those settings (swine and poultry) showed higher values of contamination by PM, it was possible to detect the existence of health effects related with PM exposure [22-24].

When comparing the results of both WSPs, it is possible to affirm that WSP B presented significantly high values in all particles sizes. This was probably due to the fact that WSP B did not have any ventilation system. Data obtained in WSP A also corroborate this fact. In that wastesorting plant, it was possible to observe some differences when the ventilation system was turned off; with higher values in that case. Several studies developed in different occupational settings have demonstrated how ventilation systems can effectively reduce the particles content in the indoor air and control occupational exposure [18,25-27]. The obtained data also allowed for the identification of the workplace (in some cases corresponding to 1 task) with higher exposure to particles in both WSPs (Figure 1). In WSP A, the worst workplace/task regarding particles exposure was that of a forklift cabinet driver. This is related not only with the higher PM concentration, but also with the fact that it was the workplace where higher concentrations of the smaller sizes were detected, which may represent different and more severe health effects [16,17]. This measurement was done during the driving and inside 
the cabinet where the worker was seated. Although the cabinet driver had a ventilation system, the obtained results are probably related with the fact that the operator maintains the cabin window open during the driving and movement of waste. Local exhaust ventilation and over-pressurized cabins equipped with dust filters at the inlet give normally good results in reducing exposure to PM, but this is dependent on the driver's behavior (e.g., opening a cabin door or window), and also on the filters maintenance [18].

In the case of WSP B, all the results from the studied workplaces were similar, probably due to the fact that all of them were taken in the same conditions: with no ventilation system. Also, the change in the type of material that was being sorted out did not induce any important differences in the results. Diverse results were obtained in a recent study developed in recycling enterprises, where it was shown that exposure to particles was higher in paper and paperboard recycling industry than in textile and plastic recycling industries [20].

In addition to mass concentration, particle number concentration was also studied and these data allowed for confirming that most of the detected particles were smaller than $0.5 \mu \mathrm{m}$. Moreover, with this exposure metric WSP B showed also the worst exposure scenario (a higher particle number concentration in all diameter sizes). Although health effects related with exposure have mainly been investigated with mass-measuring instruments or gravimetric analysis, there are some studies supporting that particle count may have advantages over particle mass concentration for assessing the health effects of airborne PM [14,15]. It can be an alternative metric that gives more detail information regarding the number of particles that can reach and get deposited onto the walls of the respiratory tract [28].

One of the major limitations of the study was the particle counter used because it cannot detect particles under $0.3 \mu \mathrm{m}$, implying the underestimation of the total particle number and the knowledge related with ultrafine particles $(<1 \mu \mathrm{m})$ exposure. Although they contribute very little to the overall mass, the concern regarding this absent information is due to the higher toxicity of ultrafine particles. The ultrafine particles are known to induce the greatest amount of inflammation per unit, greater internal doses because of high lung deposition efficiency, enhanced oxidant capacity, and they also have the ability to induce oxidative DNA damage and possibly to enter the systemic circulation in humans [28-31]. In addition, the fact that the PM assessment only involved 5 min of sampling can influence the final results and important information regarding exposure characteristics may be missing.

Besides mass and particle number concentration, there are other aspects that must be contemplated when considering the PM-related health effects: the chemical properties, that were not possible to be studied in this research, and also the fact that PM may act as a carrier and a source of nutrients for fungi (such as Aspergillus, Penicillium and Mucor genus) [32] and bacteria [33,34]. PM is also rich in endotoxins from the cell wall of gram-negative bacteria and is associated with mycotoxins produced by several fungi [35-37]. These biologically active compounds adhered to PM, along with coexisting toxicant gases that can be carcinogenic, allergic and irritant, promote concern regarding exposure to mixtures and possible additive and synergistic health effects [38].

Considering this scenario, it becomes a challenge to recognize what the specific agent or mixture is that can cause health effects and, consequently, to develop preventive measures. An important fact is the relevance of applying measures to reduce airborne particles, because biological agents like fungi are mainly transported by them [20]. Possible measures that could be taken are, for instance, the guarantee of the existence of ventilation systems in the sorting booths, the use of adequate protective equipment, the education encouraging the adequate use of the ventilation systems, the installation of extractor hoods in zones with potential risk and, in some cases, the humectation of 
waste to avoid emission and dispersion of particles and, as a result, bioaerosols [39].

\section{CONCLUSIONS}

The developed study allowed for the recognition that workers are exposed to PM. Particle counting provided additional information that is of extreme importance for analyzing the health effects of PM, since higher values of particles concentration were obtained in the smallest fraction $(0.3 \mu \mathrm{m})$, which is associated with the worst health effects. Additionally, it was possible to observe the influence that ventilation systems may have in reducing the contamination by PM.

\section{REFERENCES}

1. Park D, Ryu S, Kim S, Yoon C. An assessment of dust, endotoxin, and microorganism exposure during waste collection and sorting. J Air Waste Manage Assoc. 2011;61:461-8, http:// dx.doi.org/10.3155/1047-3289.61.4.461.

2. Rushton L. Health hazards and waste management. Br Med Bull. 2003;68:183-97, http://dx.doi.org/10.1093/bmb/ldg034.

3. Malmros P, Sigsgaard T, Bach B. Occupational health problems due to garbage sorting. Waste Manag Res. 1992;10: 227-34, http://dx.doi.org/10.1177/0734242X9201000303.

4. Sigsgaard T, Malmros P, Nersting L, Petersen C. Respiratory disorders and atopy in Danish refuse workers. Am J Respir Crit Care Med. 1994;149:1407-12, http://dx.doi.org/10.1164/ ajrccm.149.6.8004291.

5. Heldal K, Halstensen AS, Thorn J, Djupesland P, Wouters I, Eduard W, et al. Upper airway inflammation in waste handlers exposed to bioaerosols. Occup Environ Med. 2003;60:444-50, http://dx.doi.org/10.1136/oem.60.6.444.

6. Fischer G, Albrecht A, Jäckel U, Kämpfer P. Analysis of airborne microorganisms, MVOC and odour in the surrounding of composting facilities and implications for future investigations. Int J Hyg Environ Health. 2008;211(1-2):132-42, http://dx.doi.org/10.1016/j.ijheh.2007.05.003.
7. Domingo JL, Nadal M. Domestic waste composting facilities. A review of human health risks. Environ Int. 2009;35(2): 382-9, http://dx.doi.org/10.1016/j.envint.2008.07.004.

8. Persoons R, Parat S, Stoklov M, Perdrix A, Maitre A. Critical working tasks and determinants of exposure to bioaerosols and MVOC at composting facilities. Int J Hyg Environ Health. 2010;213(5):338-47, http://dx.doi.org/10.1016/ j.ijheh.2010.06.001.

9. Eduard W, Heederik D, Duchaine C, Green B. Bioaerosol exposure assessment in the workplace: The past, present and recent advances. J Environ Monit. 2012;14(2):334-9, http://dx.doi.org/10.1039/c2em10717a.

10. Viegas S, Mateus V, Almeida-Silva M, Carolino E, Viegas C. Occupational exposure to particulate matter and respiratory symptoms in Portuguese swine barn workers. J Toxicol Environ Health A. 2013;76(17):1007-14, http://dx.doi.org/ 10.1080/15287394.2013.831720.

11. Kiviranta H, Tuomainen A, Reiman M, Laitinen S, Nevalainen A, Liesivuori J. Exposure to airborne microorganisms and volatile organic compounds in different types of waste handling. Ann Agric Environ Med. 1999;6:39-44.

12. Tolvanen O, Nykänen J, Nivukoski U, Himanen M, Veijanen A, Hänninen K. Occupational hygiene in a Finnish drum composting plant. Waste Manag. 2005;25(4):427-33, http://dx.doi.org/10.1016/j.wasman.2005.02.011.

13. Tolvanen O, Hänninen I. Occupational hygiene in two combined-drum-and-tunnel composting plants managing source separated biowaste and sludge. J Environ Health. 2007;69(9):64-71.

14. Wichmann HE, Spix C, Tuch T, Wolke G, Peters A, Heinrich J, et al. Daily mortality and fine and ultrafine particles in Erfurt, Germany. Part I: Role or particle number and particle mass. Res Rep Health Eff Inst. 2000;(98):5-86.

15. Weijers EP, Khlystov AY, Kos GPA, Erisman JW. Variability of particulate matter concentrations along roads and motorways determined by a moving measurement unit. Atmos Environ. 2004;38:2993-3002, http://dx.doi.org/10.1016/ j.atmosenv.2004.02.045. 
16. World Health Organization. Hazard prevention and control in the work environment: Airborne dust. Geneva: WHO; 1999 [cited 2013 Dec 1]. Available from: http://www.who.int/occupational_health/publications/ airdust/en.

17. Brunekreef B, Forsberg B. Epidemiological evidence of effects of coarse airborne particles on health. Eur Respir J. 2005;26:309-18, http://dx.doi.org/10.1183/09031936.05.00 001805 .

18. Wouters IM, Spaan S, Douwes J, Doekes G, Heederik D. Overview of personal occupational exposure levels to inhalable dust, endotoxin, $\beta(1 \rightarrow 3)$-glucan and fungal extracellular polysaccharides in the waste management chain. Ann Occup Hyg. 2006;50(1):39-53, http://dx.doi.org/10.1093/ annhyg/mei047.

19. Vincent J, Mark D. The basis of dust sampling in occupational hygiene: A critical review. Ann Occup Hyg. 1981;24: 375-90, http://dx.doi.org/10.1093/annhyg/24.4.375.

20. Hebisch R, Linsel G. Workers exposure to hazardous substances and biological agents in recycling enterprises. Arbeitsplatzbelastung. 2012;72(4):163-9.

21. Basinas I, Schlunssen V, Takai H, Heederik D, Omland O, Wouters IM, et al. Exposure to inhalable dust and endotoxin among Danish pig farmers affected by work tasks and stable characteristics. Ann Occup Hyg. 2013;57(8):1005-19, http://dx.doi.org/10.1093/annhyg/met029.

22. Viegas S, Faísca VM, Dias H, Clérigo A, Carolino E, Viegas C. Occupational exposure to poultry dust and effects on the respiratory system in workers. J Toxicol Environ Health A. 2013;76(4-5):230-9, http://dx.doi.org/10.1080/ 15287394.2013.757199.

23. Donham K, Haglind P, Petersen Y, Rylander R, Belin L. Environmental and health studies of farm workers in Swedish confinement buildings. Br J Ind Med. 1989;46:31-7.

24. Alencar M, Nääs I, Gontijo LA. Respiratory risks in broiler production workers. Brazil J Poult Sci. 2004;6:23-9.

25. Holmberg S, Chen Q. Air flow and particle control with different ventilation systems in a classroom. Indoor
Air. 2003;13:200-4, http://dx.doi.org/10.1034/j.1600-0668. 2003.00186.x.

26. Nij ET, Hilhorst S, Spee T, Spierings J, Steffens F, Lumens $\mathrm{M}$, et al. Dust control measures in the construction industry. Ann Occup Hyg. 2003;47(3):211-8, http://dx.doi. org/10.1093/annhyg/meg023.

27. Spee T, Hoof E, Hoof W, Noy D, Kromhout H. Exposure to wood dust among carpenters in the construction industry in the Netherlands. Ann Occup Hyg. 2007;51(3):241-8, http://dx.doi.org/10.1093/annhyg/mel075.

28. Schmid O, Möller W, Semmler-Behnke M, Ferron GA, Karg E, Lipka J, et al. Dosimetry and toxicology of inhaled ultrafine particles. Biomarkers. 2009;14(S1):67-73, http://dx.doi.org/10.1080/13547500902965617.

29. Donaldson K, Stone V, Clouter A, Renwick L, MacNee W. Ultrafine particles. Occup Environ Med. 2001;58(3):211-6, http://dx.doi.org/10.1136/oem.58.3.211.

30. Pope III C, Burnett R, Thurstone GD, Thun MJ, Calle EE, Krewski D, et al. Cardiovascular mortality and long-term exposure to particulate air pollution - Epidemiological evidence of general pathophisiological pathways of disease. Circulation. 2004;109:71-7, http://dx.doi.org/10.1161/ 01.CIR.0000108927.80044.7F.

31. Sun Q, Wang A, Jin X, Natanzon A, Duquaine D, Brook RD, et al. Long-term air pollution exposure and acceleration of atherosclerosis and vascular inflammation in an animal model. JAMA. 2005;294(23):3003-10, http:// dx.doi.org/10.1001/jama.294.23.3003.

32. Seedorf J, Hartung J, Schröder M, Linkert KH, Phillips VR, Holden MR, et al. Concentrations and emissions of airborne endotoxins and microorganisms in livestock buildings in Northern Europe. J Agric Eng Res. 1998;70:97-109, http://dx.doi.org/10.1006/jaer.1997.0281.

33. Becker S, Fenton MJ, Soukup JM. Involvement of microbial components and toll-like receptors 2 and 4 in cytokine responses to air pollution particles. Am J Respir Cell Mol Biol. 2002;27(5):611-8, http://dx.doi.org/10.1165/ rcmb. 4868 . 
34. Halstensen AS, Heldal KK, Wouters IM, Skogstad M, Ellingsen DG, Eduard W. Exposure to grain dust and microbial components in the Norwegian grain and compound feed industry. Ann Occup Hyg. 2013;57(9):1105-14, http:// dx.doi.org/10.1093/annhyg/met036.

35. Zock J-P, Heederik D, Kromhout H. Exposure to dust, endotoxin and micro-organisms in the potato processing industry. Ann Occup Hyg. 1995;39(6):841-54, http://dx.doi.org/ 10.1093/annhyg/39.6.841.

36. Mayeux PR. Pathology of the lipopolysaccharide. J Toxicol Environ Health A. 1997;51:415-35, http://dx.doi.org/ 10.1080/00984109708984034.
37. Allermann L, Poulsen OM. Inflammatory potential of dust from waste handling facilities measured as IL-8 secretion from lung epithelial cells in vitro. Ann Occup Hyg. 2000; 44(4):259-69, http://dx.doi.org/10.1093/annhyg/44.4.259.

38. von Essen SG, Donham KJ. Illness and injury in animal confinement workers. Occup Med. 1999;14(2):337-50.

39. Nadal M, Inzab I, Schuhmachera M, Figueras MJ, Domingo JL. Health risks of the occupational exposure to microbiological and chemical pollutants in a municipal waste organic fraction treatment plant. Int J Hyg Environ Health. 2009;212(6):661-9, http://dx.doi.org/10.1016/ j.ijheh.2009.06.002.

This work is available in Open Access model and licensed under a Creative Commons Attribution-NonCommercial 3.0 Poland License - http://creativecommons.org/ licenses/by-nc/3.0/pl/deed.en. 